Journal of Computer Science 8 (3): 323-328, 2012

ISSN 1549-3636

(C) 2012 Science Publications

\title{
Role of Information Technology Infrastructure Library in E-Government
}

\author{
${ }^{1}$ Mihyar Hesson, ${ }^{1}$ Tariq Rahim Soomro and ${ }^{2}$ Okan Geray \\ ${ }^{1}$ College of Engineering and Information Technology, \\ $\mathrm{Al}$ Ain University of Science and Technology, Al Ain, United Arab Emirates \\ ${ }^{2}$ Strategic Planning, Dubai E-Government, Dubai, United Arab Emirates
}

\begin{abstract}
Problem statement: The E-Government implementation has achieved by many countries. This is meant to improve the delivery of public services to citizens, business and governmental departments alike. Different strategies are used to build E-Government infrastructure and deliver its services to the public. The degree of success that is achieved by different E-Governments in terms of service level and quality of service varies significantly. Approach: The objective of achieving eGovernance goes far beyond mere computerization of standalone back office operations. Strict measures are required to help E-Governments evaluate the service level and assess the quality of service. Results: In this study we introduce the E-Government strategies, perspectives, implementation, transformation and their major problems. In this context, the role of Information Technology Infrastructure Library (ITIL) is reviewed. Conclusion: Dubai E-Government (DeG) which was officially launched in December 2001 is selected as a case study for service management assessment based on ITIL standards. Two main areas of DeG service management were selected; service support and service delivery.
\end{abstract}

Key words: Dubai E-government, service support, service delivery

\section{INTRODUCTION}

The E-Government concept has been defined by various organizations (Mihyar and Okan, 2010, Isa et al., 2011). According to the Information for Development Program "E-Government is the use of ICT (Information and Communication Technologies) to transform government by making it more accessible, effective and accountable" and according to the United Nations Public Administration Network UNPAN.ORG, 2011 E-Government is defined as a government that applies ICT to transform its internal and external relationships. The use of ICT is not enough to fulfill the today's changing citizen and businesses expectations, so transition from E-Government to eGovernance is required to have a good governance concept for all the stakeholders. The e-Governance means govern and strengthen the interaction between Government (G) and Citizens (C) in two ways (G2C and $\mathrm{C} 2 \mathrm{G})$, Government $(\mathrm{G})$ and Businesses (B) in also two ways (G2B and B2G) and internal government to government operations for example G2G (Reddick, 2010). Generally, E-Government activities can benefit from government agencies, businesses and citizens
(Bhuiyan et al., 2011). E-Government involves the use of ICT to provide government information and services, most prominently through the around the clock availability of the World Wide Web (Isa et al., 2011). E-Government activities involve managerial, consultative and participatory interactions between the sectors of government, businesses and citizens (Chadwick and May, 2003).

On the other hand, Information Technology Infrastructure Library (ITIL) is a set of best practices standards for Information Technology service management. It took its name from a series of publications written by dedicated IT professionals and industry experts. ITIL provides guidance on Best Practice IT-Service Management-ITSM (Soomro and Wahba, 2011). ITIL provides businesses with a customizable framework of best practices to achieve quality service and overcome difficulties associated with the growth of IT systems. ITIL is organized into sets of texts which are defined by the Service Support and Service Delivery along with security management, application management and ICT infrastructure management (Mihyar and Okan, 2010). This study will focus on the role of ITIL in E-Government. Next "Material and Methods" will introduce the role of ITIL

Corresponding Author: Mihyar Hesson, College of Engineering and Information Technology,

Al Ain University of Science and Technology, Al Ain, United Arab Emirates 
in E-Government in general; later "Result" will explore Dubai E-Government perspective; and finally the study will discuss the overall impact of ITIL in EGovernment.

\section{MATERIALS AND METHODS}

The focus of this study is on E-Governments' service management delivery, support and quality using the well known best practices for Information Technology ITIL. ITIL is organized into sets of texts which are defined by the Service Support and Service Delivery ITIL and ITSM World, 2006. ITIL Service Support is the practice of six disciplines that enable IT Services to be provided effectively. It is also a means to ensure that the information technology area can support the IT applications that furnish business functions. These disciplines are:

- Configuration management

- Incident and problem management

- Change management

- $\quad$ Service/help desk

- Release management

ITIL Service Delivery is the management of the IT services themselves. It involves a number of management practices to ensure that IT services are provided as agreed between the service provider and the customer. Service Delivery consists of five disciplines, these are:

- $\quad$ Service level management

- Capacity management

- Continuity management

- Availability management

- IT financial management

ITIL provides a systematic approach for achieving pre-defined service levels for various service characteristics. The processes identified, designed and implemented as part of ITIL framework can be considered as a tool or means to achieve the predefined service levels for E-Government services. On the other hand, E-Government enables provisioning of public services over innovative channels. EGovernment services require certain service levels to be achieved as they replace services over the traditional channels. E-Government also increases the dependence of government agencies on information technology based services. The actual ITIL processes can be thought of as strategic trade-offs among different alternatives. Needless to say, targeting 99.5 versus $99.9 \%$ availability (service level) of an EGovernment service will inherently require different processes for achieving them. Hence target service levels will impose constraints on target service delivery processes. ITIL allows decision makers, planners and managers to address information technology services related issues in a coherent and unified framework. It also allows concomitant management of information technology services. From a managerial perspective, services, associated target service levels and achieving target service levels are different activities. The first two, namely services and associated target service levels, define and identify the target service, whereas, achieving the target service will require the design and implementation of various business processes. ITIL is one well-defined method to accomplish this. The progressive growth and abundance of information technology services (as can be seen in EGovernment and e-Business initiatives) render ITIL an invaluable tool to define and implement information technology services.

\section{RESULTS}

According to dubai statistics centre, Dubai is a city of population of almost 2 million and has a blend of over 150 nationalities live in harmony. Dubai is expanding fast and is increasingly housing international business, entertainment, media and technology. Besides its spatial expansion, Dubai is racing against the clock in its advancement in cyberspace, particularly its E-Government migration. A day can hardly pass without enhancing an existing eService, offering a new eService, launching an electronic initiative, or starting a journey towards the digital world. The story of DeG began when top officials at the Dubai Emirate expressed their vision of establishing an E-Government and inspired all government departments to bring their services online in only 18 months. Many looked at the idea as overly-ambitious and even unachievable. But in December 2001, with an official portal and some government departments offering services online, the E-Government was officially launched. Dubai has introduces 2600 e-services so far, has taken a lead with launching of mobile e-services through mDubai [http://www.mdubai.ae/]. The E-Government project that continues to evolve in Dubai joined the Good governance for development in Arab countries initiative, launched in 2005. The establishment of eservices and addressing the potential co-operation between the government departments and the private sectors, increase customer satisfaction levels and achieved a tremendous success through the automation of government services. 
Table 1: Assessment categories

\begin{tabular}{|c|c|c|c|c|c|c|c|c|c|c|c|}
\hline \multirow[b]{2}{*}{ Level } & \multicolumn{5}{|c|}{ Service delivery } & \multicolumn{6}{|c|}{ Service support } \\
\hline & $\begin{array}{l}\text { Service level } \\
\text { management }\end{array}$ & $\begin{array}{l}\text { Financial } \\
\text { management }\end{array}$ & $\begin{array}{l}\text { Capacity } \\
\text { management }\end{array}$ & $\begin{array}{l}\text { Continuity } \\
\text { management }\end{array}$ & $\begin{array}{l}\text { Availability } \\
\text { management }\end{array}$ & $\begin{array}{l}\text { Service } \\
\text { desk }\end{array}$ & $\begin{array}{l}\text { Incident } \\
\text { management }\end{array}$ & $\begin{array}{l}\text { Problem } \\
\text { management }\end{array}$ & $\begin{array}{l}\text { Configuration } \\
\text { management }\end{array}$ & $\begin{array}{l}\text { Change } \\
\text { management }\end{array}$ & $\begin{array}{l}\text { Release } \\
\text { management }\end{array}$ \\
\hline 1.0 & \\
\hline 1.5 & \multicolumn{11}{|c|}{ Management intent } \\
\hline 2.0 & \multirow{2}{*}{\multicolumn{11}{|c|}{$\begin{array}{l}\text { Process capability } \\
\text { Internal integration }\end{array}$}} \\
\hline 2.5 & \multirow{2}{*}{\multicolumn{11}{|c|}{$\begin{array}{l}\text { Internal integration } \\
\text { Products }\end{array}$}} \\
\hline 3.0 & & & & & & & & & & & \\
\hline 3.5 & \multicolumn{11}{|l|}{ Quality control } \\
\hline 4.0 & \multicolumn{11}{|c|}{ Management information } \\
\hline 4.5 & \multicolumn{11}{|c|}{ External integration } \\
\hline 5.0 & \multicolumn{11}{|c|}{ Customer interface } \\
\hline
\end{tabular}

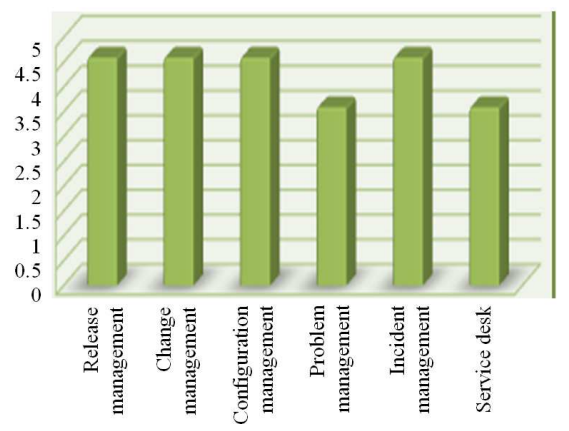

Fig. 1: Service support assessment

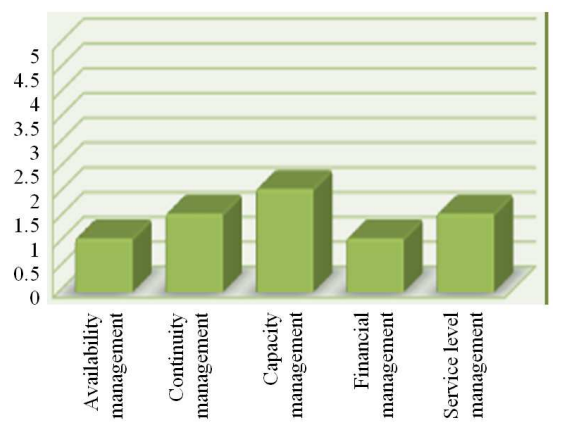

Fig. 2: Service delivery assessment

The Control Objectives for Information and related Technology (COBIT) framework COBIT-Case Study, 2011 has been used by the Dubai government audit department towards the usage of technologies and implementation of plan, policies and procedures for the IT Governance M-GovWorld, 2011.

The aim of the assessment plan is to evaluate the level of service of DeG and to find out how well it is performing compared to ITIL best practice. The assessment plan also aims to create awareness of management and control issues that may be addressed to improve the overall process capability. Table 1 illustrates how the assessment is categorized.

Eleven different categories were evaluated; six of them under Service Delivery and the other five under service support. Each category has nine different levels starting from level 1 and ends at level 5. At each level a number of service criteria are identified. This number varies from a level to another and from a service to another. To pass a level, it is not necessary to pass all the listed service criteria but a subset of it. However some of these services are mandatory to pass for the whole level to be considered a pass. Starting at Level 1 and continue up the levels until the service criteria for the current level are not met. For example, should the service criteria be satisfied for levels 1, 1.5, 2, 2.5, but not met for Level 3, then no further checks need to be attempted and the organization's capability level is deemed to be 2.5. This is so even if the service criteria are met at level 3 and/or any other higher level. This process is repeated for all the other categories. At each level of a category there are a variable number of service criteria to be met. These service criteria are different at each level of the same category and also at the similar levels of the different categories.

The self-assessment of DeG with respect to ITIL standards gives very mixed results. On one hand it has scored fairly well in service support categories while on the other hand it didn't do well in Service Delivery. For instance, it achieved level 4.5 for Configuration, Change and Release Management and level 3.5 for Service Desk and Problem Management (Fig. 1). The status is different with ITIL service delivery. DeG has achieved level 2 for capacity management, level 1.5 for service level Management and continuity management and level 1 for financial and availability management (Fig. 2).

To fairly rank DeG Service Support based on ITIL, we propose to give one point by each achieved level and divide this by the total number of levels for all components as follows (First level is 1 and maximum number of levels is 9).

Total Number of Achieved Levels/Total Number of Levels $=44 / 54=81.5 \%$. 


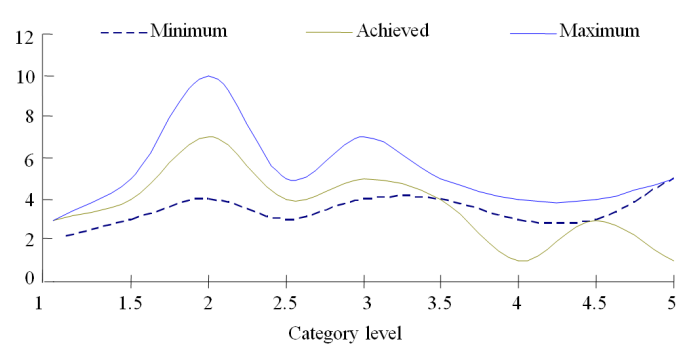

Fig. 3: Service desk

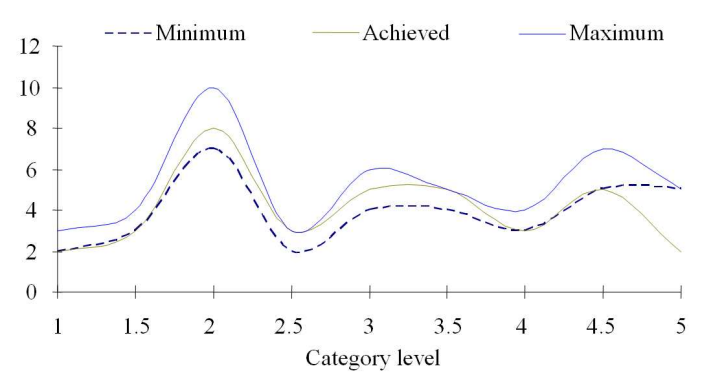

Fig. 4: Incident management

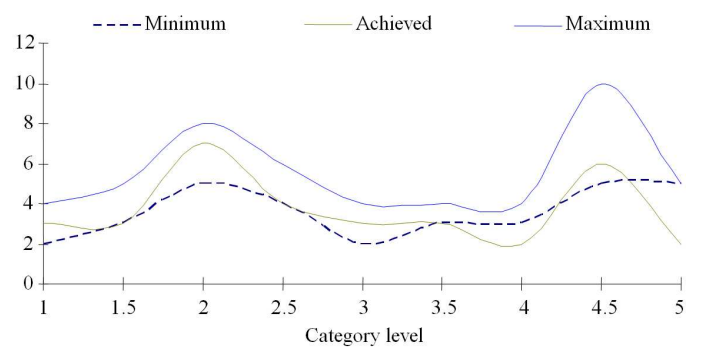

Fig. 5: Problem management

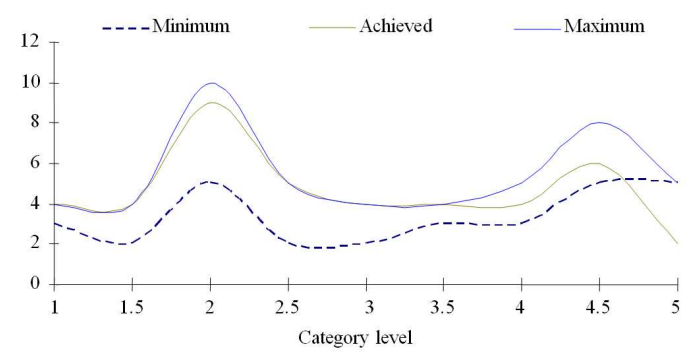

Fig. 6: Configuration management

To mark DeG service delivery based on ITIL, we propose to give one point by each achieved level and divide this by the total number of levels for all components as follows (First level is 1 and maximum number of levels is 9):

Total number of achieved levels/total number of levels $=9 / 45=20 \%$

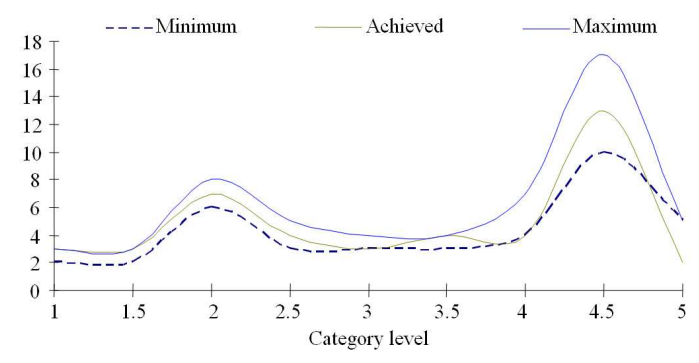

Fig. 7: Change management

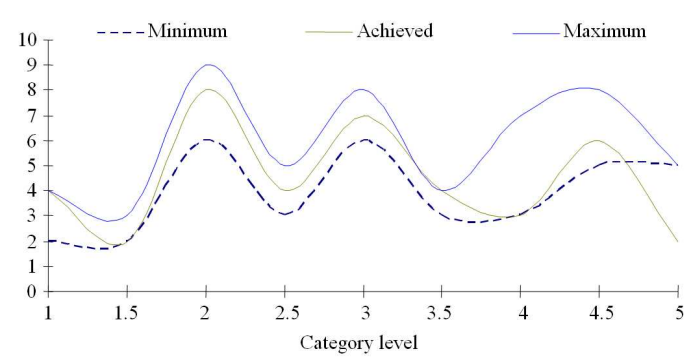

Fig. 8: Release management

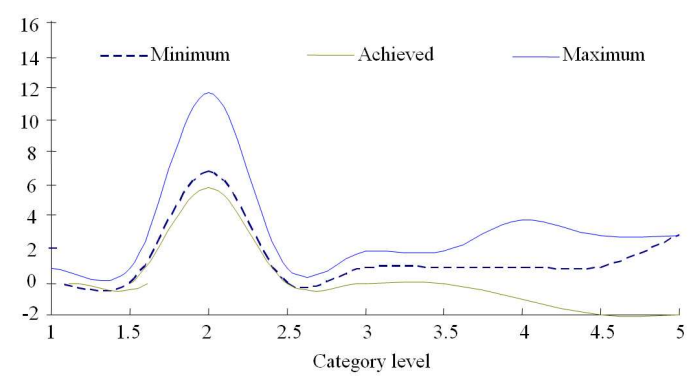

Fig. 9: Service Level management

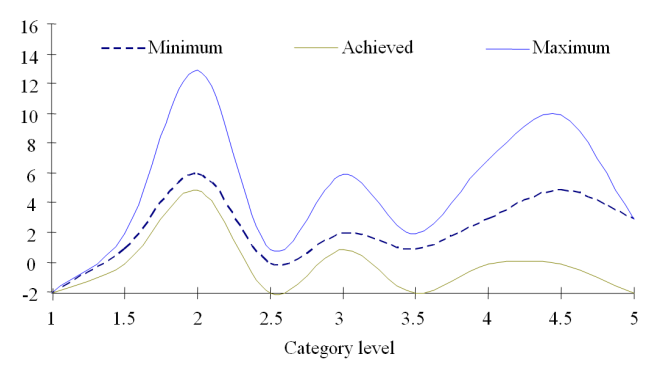

Fig. 10: Financial management

More detailed assessment analysis: In the above highlight analysis we only showed if a particular service has achieved a specific level or not. It is not clear how good or how bad the service is. The reason we are saying that is that the range between the minimum accepted level for a pass and the maximum level that can be achieved can be wide. 


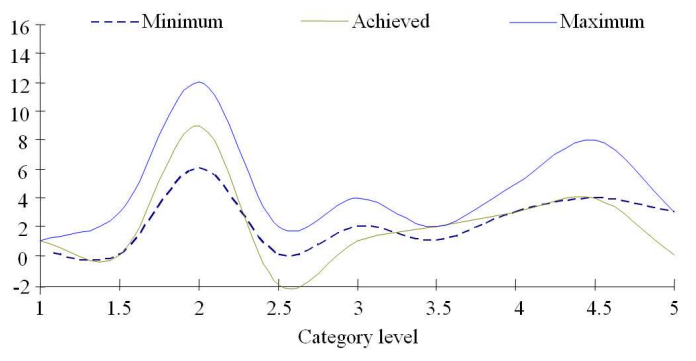

Fig. 11: Capacity management

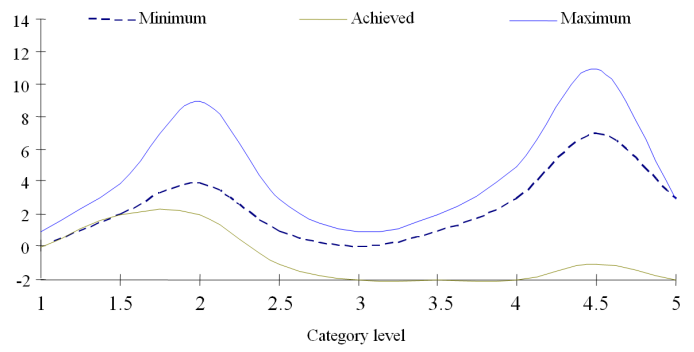

Fig. 12: Continuity management

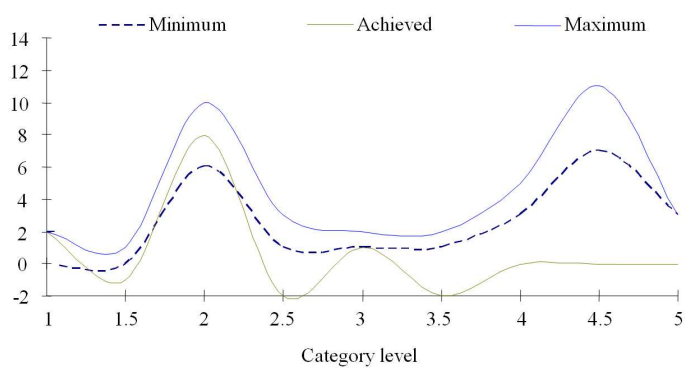

Fig. 13: Availability management

In many cases the achieved levels are on the minimum side while some of not-achieved levels are just below the minimum. This is actually not very helpful for the people at DeG to judge how much work is required at each level whether it is achieved or not. Therefore a detailed analysis for each service at the different nine levels is required. This is shown in Fig. 3-13. The achieved level of service is shown in the thick bold line while the maximum possible level is in thin bold. The minimum level is given in broken thin line. These graphs indicate precisely the current level and the amount of work required to improve it.

\section{DISCUSSION}

This study is aimed to assess the level of service management of DeG as a case study of the application of ITIL in E-Governments. This requires that DeG e-Services will have to match the international standards of E-Government service management, both in Service Delivery and Service Support. The launch of the web and mobile portals by DeG was broadly aimed at providing maximum number of government services online to citizens, residents, visitors and businesses in Dubai, while encouraging the use of electronic services to complement Dubai's vision of e-Governance MGovWorld, 2011. They include aggregated general public services portal like Dubai.ae (http://www.dubai.ae) and the mobile portal mDubai.ae (http://www.mdubai.ae). They also include one-stop-shop public services like eJob; eComplain; ePay and eLibrary. Core and channel enabling services design and develop core enabling synergistic services and these include electronic payment services like ePay and mPay; mobile messaging services (mDubai); electronic surveys (eSurvey); cross-government information exchange (SYNC); a unified government services repository (GESS); hosting portal services (eHost) and multichannel contact Centers (AskDubai). The citizen can pay DEWA (Dubai Electricity and Water Authority) Bills online; pay Traffic Fines for RTA (Road and Transport Authority); Telecom bill payment for Etisalat and DU; Renew Health Card; Check Labor Card Information; Visa Information and many more to come. All these services are also incorporated by the partnership of government organizations with the local banks through their online services [http://www.dubai.ae]. Despite all these efforts we found that the ITIL standards adopted by some EGovernments among other IT services represent a leading edge in that field. A major part of the work was devoted to draw a comprehensive self assessment plan that can be used to evaluate the DeG current and future e-services. this plan was carefully drawn after a thorough investigation of the quality standards of the e-services of e-governments and other it services worldwide.

Eleven different categories of service management were evaluated; six of them under Service support and the other five under Service Delivery. DeG scored fairly well in the Service Support with a score of $81.5 \%$. Pre-requisites, management intent, process capability, internal Integration, products and quality control requirements of ITIL service support are satisfied by DeG. Service desk, for instance, has achieved level 4.5 but failed to achieve level 4 . therefore the recognized level is set to 3.5. similarly, problem management has achieved level 4.5 but failed to achieve level 4. little study is required to raise these two categories to level 4.5 and hence raise the overall 
score to $88.9 \%$. When it comes to the performance of the Service Delivery, the picture is completely different. None of these remaining five categories has scored well. The overall performance of DeG Service Delivery could not achieve more than $20 \%$ on ITIL standards. DeG is required to do a hard work to improve their Service Delivery to an acceptable ITIL level.

\section{CONCLUSION}

The beauty of ITIL is that it is not a fixed methodology, it's a framework. One does not have to follow it step by step. It is more important for the organization planning to implement ITIL to have a clear vision about the expected achievements. They should determine if they simply want to raise operations to a new level to satisfy customer demands or they are merely looking for their IT team to earn certification in an internationally recognized standard. Not every aspect of ITIL might be applicable for a particular organization. They have to extract the best practices that will really help their organization and their business move forward and leave out those that they do not believe will add any value. The following are some common wrong practices in the implementation of ITIL that DeG should avoid (Mihyar and Okan, 2010):

- Running the implementation as an IT project instead of an organization change project

- Improper balance between strategic efforts and short-term wins

- Sole focus on one or several ITIL processes instead of all service support and delivery processes

- Over-designing the ITIL process solutions

- Scoping the implementation to one processing location

- Lack of implementation governance

- Too much emphasis on process maturity as a goal or end state

- Treating the implementation as a one-time project

- Staffing the implementation effort with people in the wrong positions

The above assessment enables DeG to determine where their IT service operations on the ITIL continuum are and how their current operating practices compare to ITIL best practices. Once DeG is done with the analysis of where they want to be, they need to look at the cost in terms of time and effort it will take them to get there. At this point, they might decide to revise their vision or stay where they are. The following are some Critical factors for successful ITIL implementation for DeG:

- Full management commitment and involvement with the ITIL implementation

- A phased approach

- Consistent and thorough training of staff and management

- Making ITIL improvements in service provision and cost reduction sufficiently visible

- Sufficient investments in ITIL support tools

\section{REFERENCES}

Bhuiyan, M.A.H., C. Siwar, S.M. Ismail and R. Islam, 2011. The role of government for ecotourism development: Focusing on east coast economic region. J. Soc. Sci., 7: 557-564. DOI: 10.3844/jssp.2011.557.564

Chadwick, A. and C. May, 2003. Interaction between States and Citizens in the Age of the Internet: "eGovernment" in the United States, Britain and the European Union. Governance, 16: 271-300. DOI: 10.1111/1468-0491.00216

Isa, W.A.R.W.M., M.R. Suhami, N.I. Safie and S.S. Semsudin, 2011. Assessing the usability and accessibility of malaysia E-Government website. Am. J. Econ. Bus. Admin., 3: 40-46. DOI: 10.3844/ajebasp.2011.40.46

Mihyar, H. and G. Okan, 2010. ITIL-Based service management empirical case study. Lecture Notes Eng. Comput. Sci., 2180: 729-729.

Reddick, C.G., 2010. Comparative E-Government. 1st Edn., Springer, New York, ISBN: 1441965351, pp: 680.

Soomro, T.R. and H.Y. Wahba, 2011. Role of Information technology infrastructure library in data warehouses. Am. J. Applied Sci., 8: 13841387. DOI: 10.3844/ajassp.2011.1384.1387 